\title{
Identification of a universal antigen epitope of influenza A virus using peptide microarray
}

Qiuxia Wang ${ }^{1,2,3}$, Zhihao Sun ${ }^{1,2,3}$, Jingzhi Li $i^{4}$, Tao Qin ${ }^{1,2,3}$, Hongwei Ma ${ }^{4}$, Sujuan Chen ${ }^{1,2,3,5^{*}}$, Daxin Peng ${ }^{1,2,3,5^{*}}$ (D) and Xiufan Liu ${ }^{1,2,5}$

\begin{abstract}
Background: Hemagglutinin is a major surface protein in influenza A virus (IAV), and HA2 is relative conserved among different IAVs. It will be meaningful to identify broad-spectrum epitopes based on the HA2 protein.

Results: Overlapping peptides of the HA2 protein of the H5N1 IAV A/Mallard/Huadong/S/2005 were synthesized and loaded on modified silica gel film to form a microarray, and antisera against different subtypes of IAVs were used to screen universal epitopes. The selected epitope was further confirmed by western blotting using antipeptide immune serum and viruses rescued with amino acid substitution. The results showed that 485-FYHKCDNE CME-495 of the H5 14th peptide in HA2 had broad-spectrum binding activity with antisera against $\mathrm{H} 1, \mathrm{H} 3, \mathrm{H} 4, \mathrm{H} 5$, $\mathrm{H} 6, \mathrm{H} 7, \mathrm{H} 8, \mathrm{H} 9$, and $\mathrm{H} 10$ subtype IAV. Substitution of amino acids ( $\mathrm{K}$ or $\mathrm{D}$ ) in rescued viruses resulted in decreased serum binding, indicating that they were critical residues for serum binding activity. In Immune Epitope Database, some epitopes containing 14-4 peptide were confirmed as MHC-II-restricted CD4 T cell epitope and had effects on releasing IL-2 or IFN.
\end{abstract}

Conclusion: The identified epitope should be a novel universal target for detection and vaccine design and its ability to generate immune protection needs further exploration.

Keywords: Influenza virus, Epitope, Broad-spectrum, Peptide, Microarray

\section{Background}

Influenza A virus (IAV), a highly infectious zoonotic and variable pathogen, presents a substantial threat to public health worldwide, causing huge economic losses in the poultry industry owing to its high morbidity and mortality $[1,2]$. Since 1918 influenza H1N1 virus killed more than 50 million people, influenza virus has been receiving more and more attention [3]. Influenza viruses could infect not only animals but also humans, and there was the possibility of interspecies transmission. Study shows

\footnotetext{
* Correspondence: Chensj@yzu.edu.cn; pengdx@yzu.edu.cn

${ }^{1}$ College of Veterinary Medicine, Yangzhou University, 48 East Wenhui Road, Yangzhou, Jiangsu 225009, People's Republic of China

Full list of author information is available at the end of the article
}

that the highly pathogenic $\mathrm{H} 5 \mathrm{~N} 1$ avian influenza virus causes millions of deaths in poultry and cross-species infection in human [4]. These factors have posed a huge pressure to the surveillance of influenza viruses and prevention of influenza.

IAV is negative-strand RNA virus and belongs to the family Orthomyxoviridae. It is composed of eight gene segments that encode at least 17 different kinds of protein [5-7]. Hemagglutinin (HA) is main envelope glycoprotein and can be cleaved into the HA1 and HA2 subunit. Continual mutations result in vast changes in HA proteins and as a consequence, cross-immunity between different subtypes is extremely poor. Thus far, 18 HA subtypes have been identified, which can be

C C The Author(s). 2021 Open Access This article is licensed under a Creative Commons Attribution 4.0 International License, which permits use, sharing, adaptation, distribution and reproduction in any medium or format, as long as you give appropriate credit to the original author(s) and the source, provide a link to the Creative Commons licence, and indicate if changes were made. The images or other third party material in this article are included in the article's Creative Commons licence, unless indicated otherwise in a credit line to the material. If material is not included in the article's Creative Commons licence and your intended use is not permitted by statutory regulation or exceeds the permitted use, you will need to obtain permission directly from the copyright holder. To view a copy of this licence, visit http://creativecommons.org/licenses/by/4.0/ The Creative Commons Public Domain Dedication waiver (http://creativecommons.org/publicdomain/zero/1.0/) applies to the data made available in this article, unless otherwise stated in a credit line to the data. 
phylogenetically segmented into two large groupsGroup 1 (H1, H2, H5, H6, H8, H9, H11, H12, H13, H16, H17, and H18) and Group 2 (H3, H4, H7, H10, H14, and H15) $[8,9]$. Hence, effective universal epitopes are of great significance for the control of influenza virus.

Currently, vaccination is still considered the most effective and powerful means against IAVs, and the HA1 subunit plays a major role in immune response induced by traditional vaccines. However, immune pressure brings out mutations of HA1. As a result, it is difficult for conventional vaccines to deal with the new strains with mutations, due to lack of cross-immune protection [10]. On the contrary, HA2 subunit is located in stem and highly conserved in different subtypes of IAV. Antibodies against conformational or linear epitopes found in the HA2 are more broadly neutralizing and protective [11].

Several methods have been developed to identify conserved epitopes. Lohia et al identified three peptides containing $\mathrm{T}$ cell epitopes from the Matrix 1 protein of the H1N1 influenza virus using the immunoinformaticsbased consensus approach, which were conserved (> 90\%) among different subtypes of IAV and might to be promising candidates for universal vaccine design [12]. Ichihashi et al predicted six cytotoxic $\mathrm{T}$ lymphocyte (CTL) epitopes from internal proteins of the H5N1 highly pathogenic avian influenza by peptide prediction programs; three of which were protective and highly conserved among three different IAV subtypes [13]. Reverse-deriving epitopes by preparing numbers of monoclonal antibodies has been sought after by many people [14-16]. Li et al used four monoclonal antibodies, which can neutralize the HA of H7N9, H3N2, and H9N2 to recognize novel linear epitopes by peptidebased ELISA [17]. Zhu et al identified six critical amino acid positions $(92,145,166,167,168$, and 197) in H9 antigenic sites based on the reactivity of variant and wild-type strains with monoclonal antibodies [18]. Some conserved epitopes also have been identified in HA2 of H5 subtype IAV [19]. In this study, novel conserved epitopes in HA2 of IAV were screened by peptide microarray and antisera against different subtypes of IAVs.

\section{Results}

\section{Identification of peptides with broad-spectrum serum} binding activity

To discover serum binding activity of peptides, the chip containing 18 overlapping peptides from the HA2 protein of the H5N1 subtype IAV S strain was reacted with 15 antisera against 9 subtype IAVs. The results showed that the SNR (Signal-to-noise ratio, SNR $=(($ signal strength-background intensity)/background intensity) of reactions between the $1 \mathrm{st}$, 5th, 6th, 7th, 8th, 18th, or 19 th peptides and antisera were all lower than 2 , indicating that there was no binding activity between these peptides and antisera (Additional file 1 (Fig. S1-S4), Additional file 2). The 2nd, 3rd, 4th, 12th, 13th, 16th, or 17th peptides showed binding activity to partial sera against the H5 subtype IAVs (Additional file 1 (Fig. S1S4), Additional file 2). In contrast, H5 14th and 15th peptides not only showed positive binding activity to different serum samples against self-subtype IAVs, but also showed positive binding activity to sera against $\mathrm{H} 1, \mathrm{H} 3$, H4, H6, H7, H8, H9 or H10 subtype IAVs, indicating that the two peptides had broad-spectrum binding activity (Fig. 1, Additional file 2). As general binding activity of the H5 14th peptide to different sera was higher than that of the H5 15th peptide, and there was partial overlapping between two peptides, the H5 14th peptide (KELGNGCFEFYHKCDNECME) was selected for further study.

To verify whether the 14th peptide at the same position of other subtype IAVs had broad-spectrum serum binding activity, a peptide from the HA2 protein of the $\mathrm{H} 7$ subtype IAV was synthesized and subjected to the microarray assay. The results showed that the H7-14 peptide bound well with sera against H7 subtype IAVs, and several kinds of $\mathrm{H} 5$ and $\mathrm{H} 9$ subtype IAVs (Fig. 2E, Additional file 2), indicating that not all 14th peptides of the HA2 protein in different subtype IAVs had a broadspectrum serum binding activity.

Through PyMOL software and the online protein simulation website SWISS-MODEL, the 3D structure of the HA protein was simulated based on the sequences of S (Fig. 3). The H5 14th peptide consisted of $\alpha$-helix and loop structures, which was exposed to the surface and able to induce antibody binding.

To confirm immunogenicity, H5 14th peptide was conjugated to BSA, and used to immunize chickens. Chicken serum was collected for western-blot analysis of different subtypes of IAVs. The results showed that immune serum could bind to HA2 proteins from $\mathrm{H} 1, \mathrm{H} 3$, H4, H5, H6, H7, H8, H9, or H10 subtype IAVs (Fig. 4, Additional file 3), indicating that the H5 14th peptide was as immunogenic as a universal epitope.

\section{Identification of key amino acids for the universal epitope} To determine specific epitope, H5 14th peptide was further cut into four overlapping peptides and each peptide contained 11 amino acids. The peptides 14-1, 14-2 and 14-3 showed a few positive reactions to sera (Fig. 2a-c, Additional file 2). In contrast, SNR values of the 14-4 peptide serum binding activity were higher than 2 (Fig. 2d, Additional file 2), except for H5-04 serum (equal to 2), indicating that some key amino acids might be in the 14-4 peptide (FYHKCDNECME).

By comparing sequences and structure of the 14-4 peptide from different subtypes of IAVs (Figs. 3 and 5), a cluster of amino acids (--HKC---CM-) was conserved 

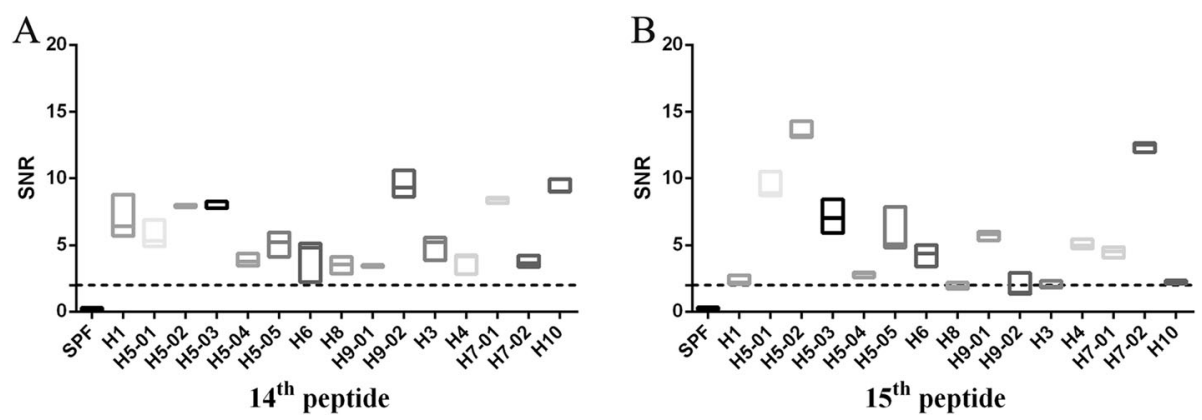

Fig. 1 The SNRs of the reaction between sera against different subtypes of IAVs and H5 14th peptide (a) or H5 15th peptide (b). Synthetic peptides were sampled onto iPDMS (modified silica gel film) to form chip, sera were diluted 1:50 (v/v) with serum dilution buffer for binding activity assay. Signal-to-noise ratio (SNR, SNR = (signal strength-background intensity)/background intensity) was determined by using GenePix Pro 6.0 software. The dotted line represents the $S N R=2$. H5-01: serum against A/Mallard/Huadong/S/2005; H5-02: serum against A/Duck/ Huadong/wx1205/2016; H5-03: serum against A/Goose/Huadong/yz1111/2016; H5-04: serum against 2.3.4.4d vaccine strain; H5-05: serum against 2.3.2.1 d vaccine strain; H7-01: serum against A/Chicken/Jiangsu/W1-8/15; H7-02: serum against A/Chicken/Huadong/JD/17; H9-01: serum against A/Chicken/Shanghai/F/98; H9-02: serum against A/Chicken/Taixing/10/2010. Each reaction was repeated for 3 times, SNR values were expressed as means \pm standard deviation. $X$ axis, sera against different subtypes of IAVs; $Y$ axis, SNR values

in most subtypes of IAVs. However, CM were located at the alpha helix region that was not easy to form epitopes [20]. So, they were not taken into consideration. Based on the sequence of five amino acids (YHKCD), 16 mutation/deletion patterns were designed (Table 1). Among these, all deletion patterns could not be applied to a rescue virus. Only when a single amino acid (Y/H/K/D) was mutated to glycine (G) could the virus be rescued. Rescued viruses were named S-Y-G, S-H-G, S-K-G, and S-D-G (biological characteristics of recombinant viruses are shown in Fig. 6). The binding activities of rescued viruses to $\mathrm{H} 5$ 14th peptide immune serum were analyzed by western-blotting. The results showed that the band intensities of viruses with substitution of amino acid $Y$ or $\mathrm{H}$ to $\mathrm{G}$ were similar to that of the wild-type strain. However, the band intensities of viruses with substitutions of the other two amino acids (K or D) to G decreased significantly (Fig. 7, Additional file 3), indicating that amino acids $\mathrm{K}$ and $\mathrm{D}$ were critical for the serum binding activity of the universal epitope.

H5 14-4 peptide was analyzed by using IEDB. The results showed that several epitopes containing partial amino acids of 14-4 peptide were confirmed as MHCII-restricted $\mathrm{T}$ cell epitope and had effects on releasing IL-2 or IFN (Table 2). However, their influence was not significant [21-23].

\section{Discussion}

Owing to natural and immune selection pressures, IAVs constantly evolve by antigenic drift or antigenic shift, resulting in influenza epidemics and recurring pandemics with serious consequences for public health and animal production [24]. Although monitoring IAV mutations to update vaccine strains is the primary method to achieve a suitable vaccine, increasingly more effort is put on finding a universal vaccine to prevent and control influenza epidemics [25-29].

The neutralizing antibody induced by the HA1 protein of IAV has a strong protective effect; however, it is well known that HA1 is highly variable. Although HA stalk based universal vaccine provides protection against group 2 IAVs [30, 31], HA2 with high sequence and structure conservation among various subtypes of IAVs are more suitable as targets for screening broadspectrum epitopes [32]. It has been proved that HA2 has universal epitopes crossing Group 1 and Group 2 IAVs $[16,17,33]$, which are usually screened by effective monoclonal antibodies and whole viruses or peptides. In this study, we applied peptide microarray with immune serum against different subtypes of IAVs to screen a universal antigenic epitope.

The peptide microarray is a new type of technology that has recently been developed [34-36]. In a dot matrix, proteins are decomposed into a plurality of peptides and dotted on silica gel film [34, 35]. It can not only detect the corresponding antibody in serum but also reverse deduce the epitope recognized by the antibody [36, 37]. Based on the peptide microarray, we screened out the H5 14th peptide, KELGNGCFEFYHKC DNECME in HA2, which was positively responsive to the antibodies against multiple subtypes of IAVs. Furthermore, the truncated peptide (FYHKCDNECME) was confirmed to play a major role in the functioning of the broad-spectrum serum binding activity. In the mimetic $3 \mathrm{D}$ protein structure, the peptide was located at the bottom of the HA stem region, while the truncated peptide was located outside the bottom of the peptide, suggesting that the peptide epitope was exposed and immunogenic. In fact, the H5 14th peptide showed well binding activity against sera collected from IAVs infected 

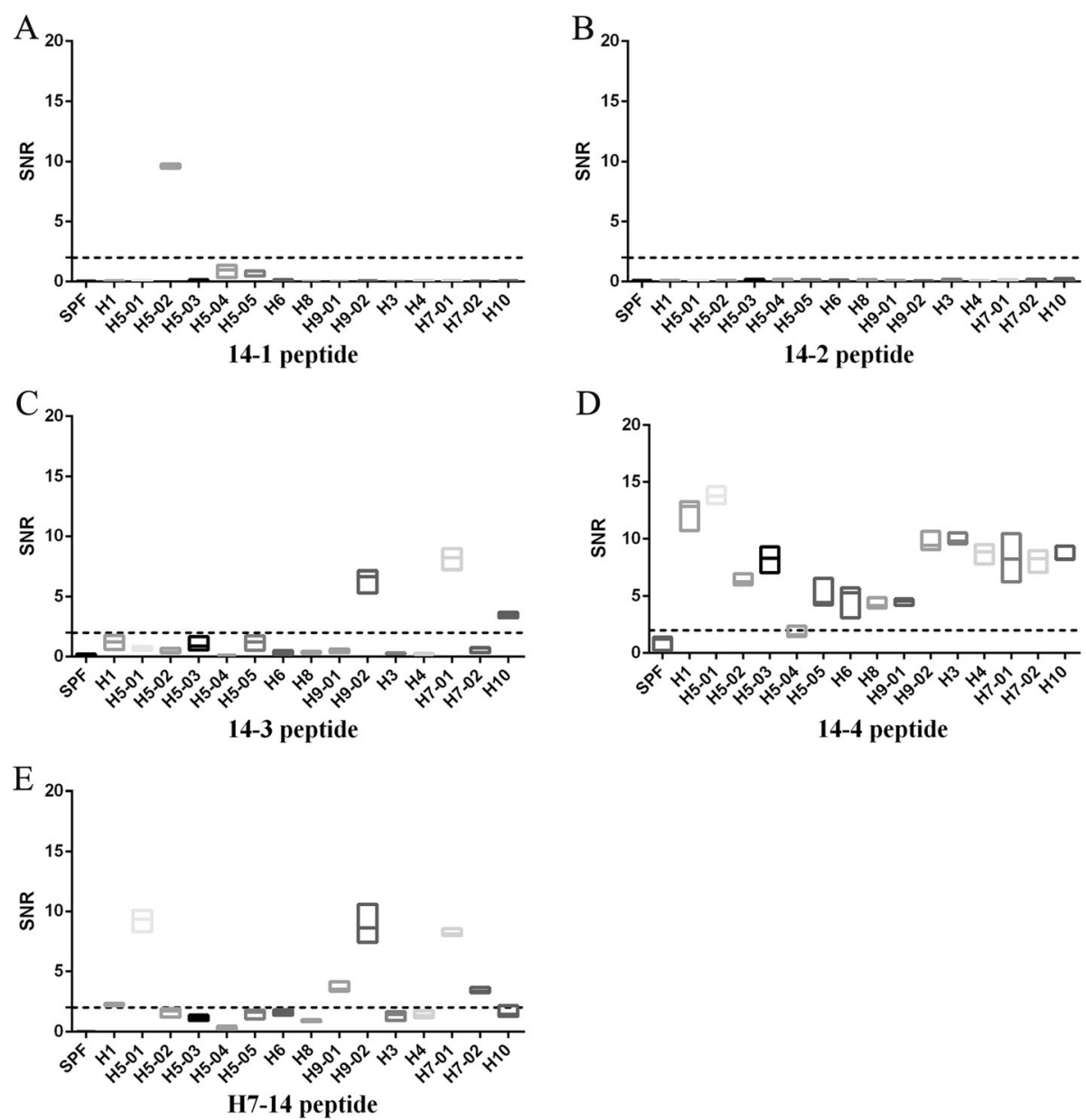

Fig. 2 The SNRs of the reaction between sera against different subtypes of IAVs and H5 14-1 (a), H5 14-2 (b), H5 14-3 (c), H5 14-4 (d) or H7-14 (e) peptides. Synthetic peptides were sampled onto iPDMS (modified silica gel film) to form chip, sera were diluted 1:50 (v/v) with serum dilution buffer for binding activity assay. Signal-to-noise ratio (SNR, SNR = (signal strength-background intensity)/background intensity) was determined by using GenePix Pro 6.0 software. The dotted line represents the SNR =2. H5-01: serum against A/Mallard/Huadong/S/2005; H5-02: serum against A/Duck/Huadong/wx1205/2016; H5-03: serum against A/Goose/Huadong/yz1111/2016; H5-04: serum against 2.3.4.4d vaccine strain; H5-05: serum against 2.3.2.1 d vaccine strain; H7-01: serum against A/Chicken/Jiangsu/W1-8/15; H7-02: serum against A/Chicken/Huadong/JD/17; H9-01: serum against A/Chicken/Shanghai/F/98; H9-02: serum against A/Chicken/Taixing/10/2010. Each reaction was repeated for 3 times, SNR values were expressed as means \pm standard deviation. $X$ axis, sera against different subtypes of IAVs; $Y$ axis, SNR values

chickens (Data not shown). However, it's confusing that the reactivity of the three different HA2 from the H501, H5-02 and H5-03 viruses against a serum specific of H5 14th peptide was different (Fig. 4). So, HA 3D simulation structures of those viruses were also simulated. According to Table 3 and Fig. 8, the H5 14th peptide sequences and structures of three viruses are not significantly different, but different protein structures around them may affect the reaction of the antibody with the epitope.

As three consecutive amino acids (HKC) were relatively conserved in the H5 14th peptide of most IAVs, a total of 16 mutation/deletion patterns of the peptide was designed to find key amino acids for binding activity based on consecutive amino acids (YHKCD). Viruses could only be successfully rescued when a single amino acid was mutated to a non-polar amino acid G, except amino acid $C$. This may demonstrate that the H5 14th peptide structure is an extremely stable conformation in the HA stem region, and any amino acid deletion of the peptide might have a strong effect on stem structure. Interestingly, amino acid $C$, which is known as the only one kind of amino acid to form intermolecular disulfide bonds, was almost completely conserved in different subtypes of IAVs. In 3D simulation (Fig. 8), 14-4 peptide is also adjacent to HA1. Substitution of C to G failed to rescue the virus, indicating the $C$ was of great significance for stabilizing protein/peptide structures [38-40]. Simultaneously, when "K/D" was mutated to G respectively, the binding activities of viruses to immune 


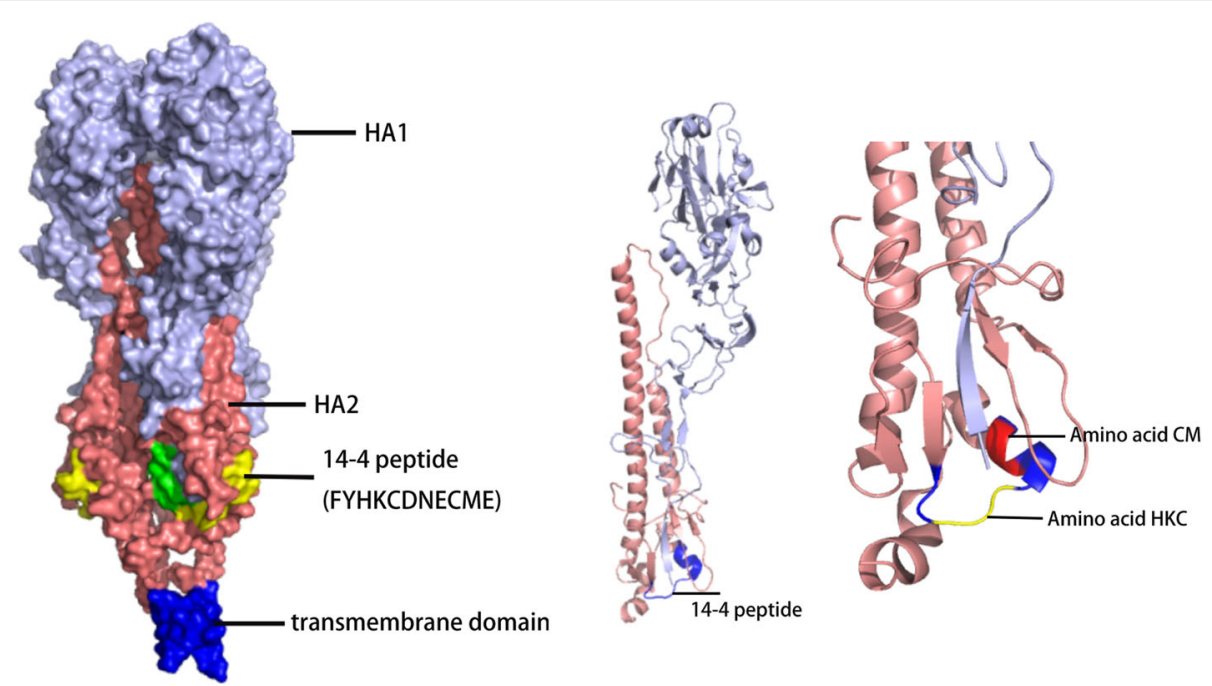

Fig. 3 Locations of 14th and 14-4 peptides in simulated HA 3D structure of S strain. The positions of peptide on the hemagglutinin (HA) molecule were analyzed using X-ray crystal structure obtained from the Protein Database. The picture was generated by the SWISS-MODEL system and the PyMOL system

serum of the H5 14th peptide decreased. Although both the H5 14th and the H7-14 peptide had the core amino acid HKCD, the former showed more broad-spectrum serum binding activity than that of the H7-14 peptide. These data suggest that the broad-spectrum epitope consists of HKCD and adjacent amino acids.

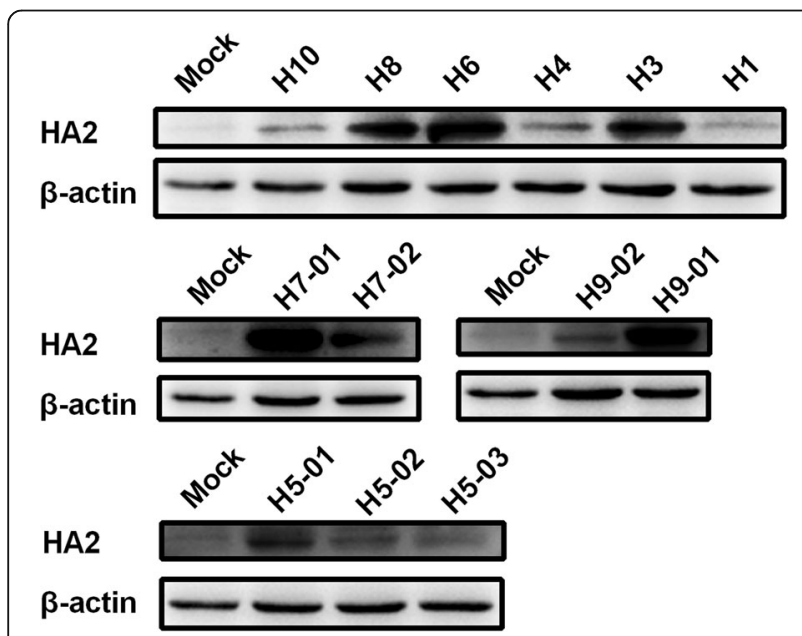

Fig. 4 Western-blotting analysis of HA2 protein from different subtypes of influenza A viruses (IAVs). Lysates (amount of protein was $50 \mu \mathrm{g}$ ) of chicken embryo fibroblasts (CEF) infected with IAVs at $\mathrm{MOI}$ of 0.01 for $12 \mathrm{~h}-15 \mathrm{~h}$ were incubated with a primary antibody (immune serum of BSA-conjugated H5 14th peptide) and a monoclonal antibody $(\mathrm{mAb})$ against $\beta$-actin. Bands were visualized using a chemiluminescence imaging analysis system after incubation with horse radish peroxidase (HRP)-labeled secondary antibodies. H5-01: A/Mallard/Huadong/S/2005; H5-02: A/Duck/Huadong/ wx1205/2016; H5-03: A/Goose/Huadong/yz1111/2016; H7-01: A/ Chicken/Jiangsu/W1-8/15; H7-02: A/Chicken/Huadong/JD/17; H901: A/Chicken/Shanghai/F/98; H9-02: A/Chicken/Taixing/10/2010
Additionally, Guo et al also found that the peptide FYHKCDNT was an immunodominant epitope in the 2009 pandemic H1N1 IAV, and the seasonal influenza viruses, induced generation of high volumes of antibodies by organisms [41]. Wang et al proved that peptide CFEFYHKCDNTCMES could be recognized by the antiserum against the $\mathrm{H} 1$ subtype swine influenza virus, and was able to generate antibody responses in pigs via intranasal inoculation [42]. Katherine et al identified that peptide YHKCNNECMESVKNGTYD and EFYHKCNN ECMES played a role in CD4 $\mathrm{T}$ cells response and facilitated the release of IL-2. However, the ELISPOT results of the two peptides only detected less than 50 IL-2producing cells per million CD4 T cells [22,23].

This study had two potential limitations. One of them was that nine sera against different subtype IAVs were used for epitope screening, the broad-spectrum of $\mathrm{H} 5$ 14th peptide should be further confirmed by sera against other subtypes IAVs. Another limitation was that H5 14th peptide for universal vaccine design should be confirmed by animal protection study.

\section{Conclusion}

A peptide FYHKCDNECME was identified demonstrating broad-spectrum serum binding activity to different subtypes of IAVs may be used as a novel universal target for detection and vaccine design.

\section{Methods}

Virus, serum, plasmid, and cells

A total of 13 strains of IAV (Table 4) isolated from live poultry markets, including nine different subtypes of IAV ( $\mathrm{H} 1, \mathrm{H} 3, \mathrm{H} 4, \mathrm{H} 5, \mathrm{H} 6, \mathrm{H} 8, \mathrm{H} 7, \mathrm{H} 9$, and $\mathrm{H} 10)$, were 

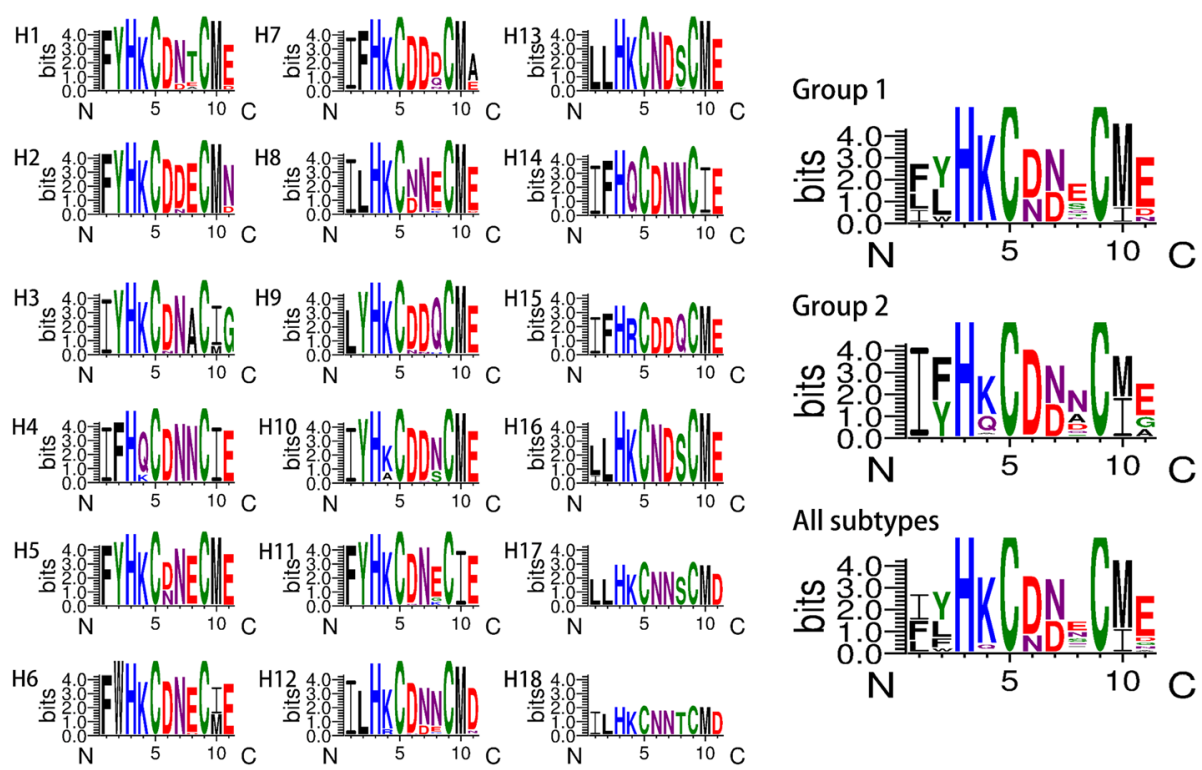

Fig. 5 Variation in 14-4 peptide in influenza A viruses was analyzed using WebLogo3. Hemagglutinin (HA) gene sequences of influenza A viruses (IAVs) available from the GISAID and GenBank were aligned by MEGA 7.0 and then analyzed by WebLogo3 (http://weblogo.threeplusone.com/)

used to prepare sera. All viruses were propagated in specific pathogen free (SPF) embryonated chicken eggs. Two kinds of sera against the H5 subtype of vaccine strains (2.3.4.4d and 2.3.2.1d) were purchased from YEBIO Company (China). The H5N1 avian influenza virus origin rescue plasmids (pHW-PB2, pHW-PB1, pHW-PA, pHW-HALo, pHW-NP, pHW-NA, pHW-M, and pHW-NS) were constructed by Shi et al [43]. Primary chicken embryo fibroblasts (CEF) were prepared from 9 to $10 \mathrm{~d}$ SPF chicken embryos and cultured in M199 (HyClone Laboratories, USA) containing 4\% fetal bovine serum (FBS, Shuangru Biotech, China).

\section{Serum preparation}

Forty-five 21-day-old SPF chickens (Beijing Meria Vitong experimental animal technology co., Ltd., China) were housed in cages under biosafety conditions with ad libitum access to food and water, three chickens in each group were immunized with inactivated IAVs $\left(10^{6}\right.$ EID $_{50}$ ) with oil emulsion adjuvant or BSA-conjugated peptides (GL Biochem Ltd., China) with Freund's adjuvant (Sigma, USA) and boosted at a two-week interval. Chickens were inoculated with PBS as control group. Chickens were euthanatized by manual cervical dislocation at 2 weeks after the second vaccination and their sera were collected and identified by hemagglutination inhibition assay for whole virus immunized antisera (Table 4), and peptide chip for peptide immunized antisera.

\section{Microarray experiment}

According to the deduced amino acid sequence of the HA2 protein of the H5 subtype virus A/Mallard/Huadong/S/2005 (S, GenBank accession numbers: EU195389-EU195396), overlapping peptides (10 amino acids overlapped between two adjacent peptides) were synthesized by GL Biochem Ltd. (China), except for the failure of the 11th peptide. To confirm key amino acids for the serum binding activity, the selected H5 14th peptide from the HA2 protein (KELGNGCFEFYHKCDNEC $\mathrm{ME)}$ was further cut into four overlapping peptides. To verify whether the selected peptide from the other

Table 1 Different mutation/deletion patterns of 14-4 peptide

\begin{tabular}{llll}
\hline Mutation & Delete $\mathbf{4}$ amino acids & Delete $\mathbf{1}$ amino acid & Delete $\mathbf{5}$ amino acids \\
\hline FGHKCDNECME & FY---NECME & F-HKCDNECME & F----NECME \\
FYGKCDNECME & F-H---NECME & FY-KCDNECME & \\
FYHGCDNECME & F--K--NECME & FYH-CDNECME & \\
FYHKGDNECME & F---C-NECME & FYHK-DNECME & \\
FYHKCGNECME & F---DNECME & FYHKC-NECME & \\
\hline
\end{tabular}

- represents deletion, bold letter represents substitution amino acid 

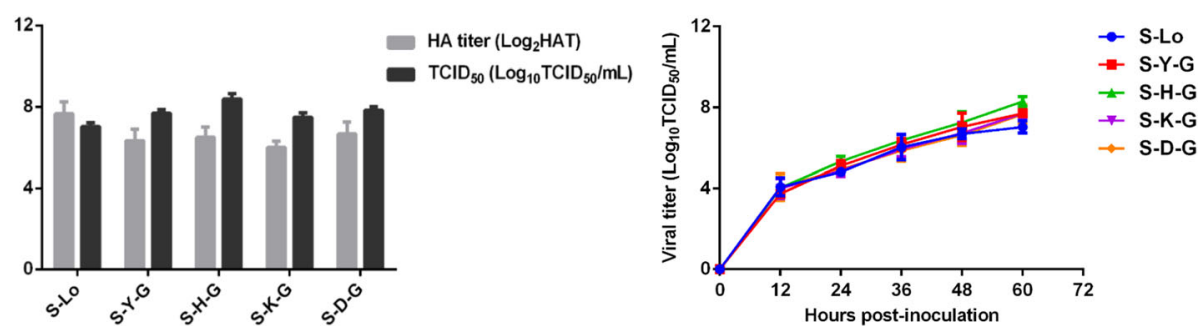

Fig. $6 \mathrm{HA}$ titer, median tissue culture infectious dose $\left(T_{C} \mathrm{DD}_{50}\right)$ and growth curve of recombinant viruses. Viruses were inoculated into chicken embryo allantoic cavity (9-day-old specific pathogen free chicken embryo, $0.25 \mu \mathrm{L}$ each) and its Hemagglutination (HA) titer was determined. $\mathrm{TCID}_{50}$ was determined through chicken embryo fibroblasts (CEF) and calculated by the Reed-Muench method. To determine growth curve, CEF were infected with each virus at MOI of 0.01 in M199 for $1 \mathrm{~h}$. The infected cells were washed with PBS and then serum-free M199 was added. Cells were incubated at $37^{\circ} \mathrm{C}$ under $5 \% \mathrm{CO} 2$. The virus titers in the supernatant were monitored periodically by determination of $\mathrm{TCID}_{50}$ in $\mathrm{CEF}$. Each reaction was repeated for 3 times, and the titers were expressed as means \pm standard deviation

subtype virus had similar serum binding activity, the H7-14 peptide from the HA2 protein (A/Chicken/Huadong/JD/17) was synthesized (Table 5). Synthetic peptides were sampled onto iPDMS (modified silica gel film) and workflow of the microarray was mainly based on the previous study [44]. Sera were diluted 1:50 (v/v) with serum dilution buffer (GuardianTM Peroxidase Conjugate Stabilizer/Diluent, Thermo Fisher Scientific, USA) and a $200 \mu \mathrm{L}$ dilution was added in each well of the chip. The chip was incubated on a shaker for $30 \mathrm{~min}$ $\left(500 \mathrm{r} / \mathrm{min}, 37^{\circ} \mathrm{C}\right)$ and subsequently washed three times with TBST (20 mM Tris-base, pH 6.8, $137 \mathrm{mM} \mathrm{NaCl}$, $0.1 \%$ Tween 20). Following incubation with $100 \mu \mathrm{L}$ of 1 : 10000 diluted HRP (horseradish peroxidase)-labeled goat anti-chicken IgY for an additional $30 \mathrm{~min}$ and washing three times with TBST, $15 \mu \mathrm{L}$ chemiluminescent substrate (SuperSignal West Pico PLUS Chemiluminescent Substrate, Thermo Fisher, USA) was added to each well of the chip. Chemiluminescent signals were captured by

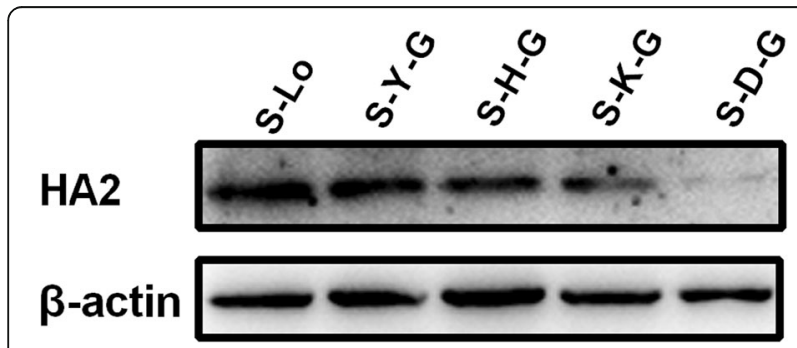

Fig. 7 Western-blotting analysis of HA2 protein from mutant viruses. Lysates (amount of protein was $50 \mu \mathrm{g}$ ) of chicken embryo fibroblasts (CEF) infected with mutant viruses at $\mathrm{MOI}$ of 0.01 for $12 \mathrm{~h}-15 \mathrm{~h}$ were incubated with a primary antibody against H5 14th peptide and monoclonal antibody (mAb) against $\beta$-actin. Bands were visualized by a chemiluminescence imaging analysis system after incubation with horse radish peroxidase (HRP)-labeled secondary antibodies. SLo: H5 IAV control strain; S-Y-G: Tyrosine (Y) in 14-4 peptide of H5 IAV was mutated by Glycine (G); S-H-G: Histidine $(\mathrm{H})$ in 14-4 peptide of H5 IAV was mutated by G; S-K-G: Lysine (K) in 14-4 peptide of H5 IAV was mutated by G; S-D-G: Asparticacid (D) in 14-4 peptide of H5 IAV was mutated by $G$ a CCD (charge coupled device) camera (LAS4000 imaging system, GE Healthcare Life Sciences, USA) and saved as an image in TIFF format. Thereafter, chemiluminescence intensity of each peptide point and background was converted into the signal-to-noise ratio (SNR, SNR = (signal strength-background intensity)/ background intensity) using GenePix Pro 6.0 software. SNR $\geq 2$ were identified as seropositive [36].

\section{Site-direct mutagenesis and virus rescue}

Site-direct mutagenesis of selected amino acid residues on the $\mathrm{S}$ strain HA2 protein was performed by the Mut Express II Fast Mutagenesis Kit V2 (Vazyme Biotech, China). Modified HA genes were inserted into the pHW2000 vector [45] and confirmed by sequencing (BGI Company, China). Recombinant viruses were rescued via an 8-plasmid reverse genetics technology as described previously [46]. HEC293T and M90 cells were plated at a ratio of approximately 1.5:1 in six-well plates and cultured in Dulbecco's Modified Eagle Medium (DMEM) medium (HyClone Laboratories, USA) containing $10 \%$ FBS. The modified HA plasmid combined with seven $S$ strain rescue plasmids were transfected using the PolyJet ${ }^{\text {Tw }}$ transfection reagent (SignaGen Laboratories, USA). At $48-72 \mathrm{~h}$ post-transfection, the cells and supernatant were collected and inoculated into chicken embryo allantoic cavity (7-day-old SPF chicken embryo, $0.25 \mu \mathrm{L}$ each) to propagate recombinant viruses. The Median Tissue Culture Infectious Dose $\left(\mathrm{TCID}_{50}\right)$ of rescued viruses in CEF were determined according to Wagner (2000) and calculated by the Reed-Muench method [47]. To determine growth curve, CEF were infected with each virus at MOI of 0.01 in M199 for $1 \mathrm{~h}$. The infected cells were washed with PBS and then serum-free M199 was added. Cells were incubated at $37{ }^{\circ} \mathrm{C}$ under $5 \% \mathrm{CO} 2$. The virus titers in the supernatant were monitored periodically by determination of $\mathrm{TCID}_{50}$ in CEF. 
Table 2 Results of 14-4 peptide analyzed in IEDB

\begin{tabular}{|c|c|c|c|c|c|c|c|}
\hline Epitope & Parent protein & Antigen name & Host & Method & Assay & Result & Reference \\
\hline $\begin{array}{l}\text { CFEFYHKCNNEC } \\
\text { MESVK }\end{array}$ & $\begin{array}{l}\text { hemagglutinin } \\
(480-496)\end{array}$ & $\begin{array}{l}\text { A/NewCaledonia/20/1999 } \\
\text { (H1N1) }\end{array}$ & Homo sapiens & ELISPOT & $\begin{array}{l}\mathrm{IFNg} \\
\text { release }\end{array}$ & Positive & $\begin{array}{l}\text { Jenny Aurielle B Babon, Hum } \\
\text { Immunol, } 2009\end{array}$ \\
\hline $\begin{array}{l}\text { YHKCNNECMESV } \\
\text { KNGTYD }\end{array}$ & $\begin{array}{l}\text { Hemagglutinin } \\
\text { (484-501) }\end{array}$ & $\begin{array}{l}\text { A/NewCaledonia/20/1999 } \\
\text { (H1N1) }\end{array}$ & $\begin{array}{l}\text { Mus musculus } \\
\text { HLA-DR1 Tg }\end{array}$ & ELISPOT & $\begin{array}{l}\mathrm{IL}-2 \\
\text { release }\end{array}$ & Positive & $\begin{array}{l}\text { Katherine A Richards, } \\
\text { Immunology, } 2011\end{array}$ \\
\hline $\begin{array}{l}\text { EFYHKCDNECME } \\
S\end{array}$ & $\begin{array}{l}\text { hemagglutinin } \\
(485-497)\end{array}$ & $\begin{array}{l}\text { A/Thailand/4(SP-528)/2004 } \\
\text { (H5N1) }\end{array}$ & $\begin{array}{l}\text { Mus musculus } \\
\text { HLA-DR1 Tg }\end{array}$ & ELISPOT & $\begin{array}{l}\mathrm{IL}-2 \\
\text { release }\end{array}$ & Positive & $\begin{array}{l}\text { Katherine A Richards, J Virol, } \\
2009\end{array}$ \\
\hline $\begin{array}{l}\text { EEMGNGCFKIYH } \\
\text { KCD }\end{array}$ & $\begin{array}{l}\text { Hemagglutinin } \\
(476-490)\end{array}$ & $\mathrm{A} / \mathrm{X}-31(\mathrm{H} 3 \mathrm{~N} 2)$ & $\begin{array}{l}\text { Mus musculus } \\
\text { C57BL/6 }\end{array}$ & ELISPOT & $\begin{array}{l}\mathrm{IFNg} \\
\text { release }\end{array}$ & Negative & Sherry R Crowe, Vaccine, 2006 \\
\hline $\begin{array}{l}\text { FEFYHKCDNECM } \\
\text { ESV }\end{array}$ & $\begin{array}{l}\text { Hemagglutinin } \\
(481-495)\end{array}$ & $\begin{array}{l}\text { A/PuertoRico/8/34/Mount } \\
\text { Sinai (H1N1) }\end{array}$ & $\begin{array}{l}\text { Mus musculus } \\
\text { C57BL/6 }\end{array}$ & ELISPOT & $\begin{array}{l}\mathrm{IFNg} \\
\text { release }\end{array}$ & Negative & Sherry R Crowe, Vaccine, 2006 \\
\hline $\begin{array}{l}\text { IGNGCFEFYHKC } \\
\text { DNE }\end{array}$ & $\begin{array}{l}\text { Hemagglutinin } \\
(476-490)\end{array}$ & $\begin{array}{l}\text { A/PuertoRico/8/34/ } \\
\text { MountSinai (H1N1) }\end{array}$ & $\begin{array}{l}\text { Mus musculus } \\
\text { C57BL/6 }\end{array}$ & ELISPOT & $\begin{array}{l}\mathrm{IFNg} \\
\text { release }\end{array}$ & Negative & Sherry R Crowe, Vaccine, 2006 \\
\hline $\begin{array}{l}\text { AEDMGNGCFKIY } \\
\text { HKCDN }\end{array}$ & $\begin{array}{l}\text { Hemagglutinin } \\
(475-491)\end{array}$ & $\begin{array}{l}\text { A/New York/384/2005 } \\
(\mathrm{H} 3 \mathrm{~N} 2)\end{array}$ & Homo sapiens & ELISPOT & $\begin{array}{l}\mathrm{IFNg} \\
\text { release }\end{array}$ & Negative & $\begin{array}{l}\text { Jenny Aurielle B Babon, Hum } \\
\text { Immunol, } 2009\end{array}$ \\
\hline $\begin{array}{l}\text { AKELGNGCFEFY } \\
\text { HKCDN }\end{array}$ & $\begin{array}{l}\text { Hemagglutinin } \\
(476-492)\end{array}$ & $\begin{array}{l}\text { A/Thailand/4(SP-528)/2004 } \\
\text { (H5N1) }\end{array}$ & Homo sapiens & ELISPOT & $\begin{array}{l}\mathrm{IFNg} \\
\text { release }\end{array}$ & Negative & $\begin{array}{l}\text { Jenny Aurielle B Babon, Hum } \\
\text { Immunol, } 2009\end{array}$ \\
\hline $\begin{array}{l}\text { GCFEFYHKCDNE } \\
\text { CMESV }\end{array}$ & $\begin{array}{l}\text { Hemagglutinin } \\
\text { (482-498) }\end{array}$ & $\begin{array}{l}\text { A/Thailand/4(SP-528)/2004 } \\
\text { (H5N1) }\end{array}$ & Homo sapiens & ELISPOT & $\begin{array}{l}\mathrm{IFNg} \\
\text { release }\end{array}$ & Negative & $\begin{array}{l}\text { Jenny Aurielle B Babon, Hum } \\
\text { Immunol, } 2009\end{array}$ \\
\hline $\begin{array}{l}\text { HKCDNECMESVR } \\
\text { NGTYD }\end{array}$ & $\begin{array}{l}\text { Hemagglutinin } \\
(488-504)\end{array}$ & $\begin{array}{l}\text { A/Thailand/4(SP-528)/2004 } \\
\text { (H5N1) }\end{array}$ & Homo sapiens & ELISPOT & $\begin{array}{l}\mathrm{IFNg} \\
\text { release }\end{array}$ & Negative & $\begin{array}{l}\text { Jenny Aurielle B Babon, Hum } \\
\text { Immunol, } 2009\end{array}$ \\
\hline $\begin{array}{l}\text { GNGCFEFYHKCN } \\
\text { NECMES }\end{array}$ & $\begin{array}{l}\text { Hemagglutinin } \\
(477-494)\end{array}$ & $\begin{array}{l}\text { A/NewCaledonia/20/1999 } \\
\text { (H1N1) }\end{array}$ & $\begin{array}{l}\text { Mus musculus } \\
\text { HLA-DR1 Tg }\end{array}$ & ELISPOT & $\begin{array}{l}\mathrm{IL}-2 \\
\text { release }\end{array}$ & Negative & $\begin{array}{l}\text { Katherine A Richards, J Virol, } \\
2007\end{array}$ \\
\hline
\end{tabular}

\section{Western-blot analysis}

Chicken embryo fibroblasts was inoculated with viruses $(\mathrm{MOI}=0.01)$ and incubated for $1 \mathrm{~h}$ at $37^{\circ} \mathrm{C}$. Cells were washed twice with phosphate buffered saline (PBS, pH 7.2). Thereafter, M199 medium containing 1\% FBS was added and incubated for $12 \mathrm{~h}$. Cells were washed once with pre-cooled PBS $\left(4^{\circ} \mathrm{C}\right)$ and lysed with $200 \mu \mathrm{L}$ of RIPA Lysis Buffer (strong) (CWBIO, Beijing, China) individually on ice for 15-20 min. Supernatants were collected by centrifugation at $12000 \mathrm{r} / \mathrm{min}$ for $10 \mathrm{~min}$ at $4{ }^{\circ} \mathrm{C}$ and mixed with protein loading buffer (Beyotime Biotechnology, China). Following boiling at $100^{\circ} \mathrm{C}$ for 6-8 min, samples were subjected to $12 \%$ SDS-PAGE, and transferred to a PVDF membrane. The membrane which was first blocked in TBST containing 5\% non-fat powdered milk at $25^{\circ} \mathrm{C}$ for $1 \mathrm{~h}$ was incubated with the primary antibody against the $\mathrm{H} 5$ 14th peptide (diluted to 1:1000 with TBST), and then incubated with the

Table 3 Amino acid sequences of 14th peptide and 14-4 peptide of 13 virus

\begin{tabular}{llll}
\hline Virus & Type & 14th peptide & 14-4 peptide \\
\hline A/Duck/Eastern China/103/2003 & H1N1 & KEIGNGCFEFYHKCNNECME & FYHKCNNECME \\
A/Duck/Eastern China/852/2003 & H3N2 & EDMGNGCFKIYHKCDNACIE & IYHKCDNACIE \\
A/Duck/Eastern China/160/2002 & H4N6 & EDKGNGCFEIFHQCDNNCIE & IFHQCDNNCIE \\
A/Mallard/Huadong/S/2005 & H5N1 & KELGNGCFEFYHKCDNECME & FYHKCDNECME \\
A/Duck/Huadong/wx1205/2016 & H5N1 & KELGNGCFEFYHKCNNECME & FYHKCNNECME \\
A/Goose/Huadong/yz1111/2016 & H5N6 & EELGNGCFEFYHKCDNECME & FYHKCDNECME \\
A/Duck/Eastern China/58/2003 & H6N2 & NDLGNGCFEFWHKCDNECIE & FWHKCDNECIE \\
A/Chicken/Jiangsu/W1-8/15 & H7N9 & EEDGTGCFEIFHKCDDDCMA & IFHKCDDDCMA \\
A/Chicken/Huadong/JD/17 & H7N9 & EEDGTGCFEIFHKCDDDCMA & FHKCDDDCMA \\
A/Duck/Eastern China/01/2005 & H8N4 & IDAGNGCFDILHKCDNECME & ILHKCDNECME \\
A/Chicken/Shanghai/F/98 & H9N2 & MEDGKGCFELYHKCDDQCME & LYHKCDDQCME \\
A/Chicken/Taixing/10/2010 & H9N2 & MEDGKGCFELYHKCDNQCME & LYHKCDNQCME \\
A/Chicken/Huadong/RD5/2013 & H10N9 & EEDGKGCFEIYHKCDDNCME & IYHKCDDNCME \\
\hline
\end{tabular}




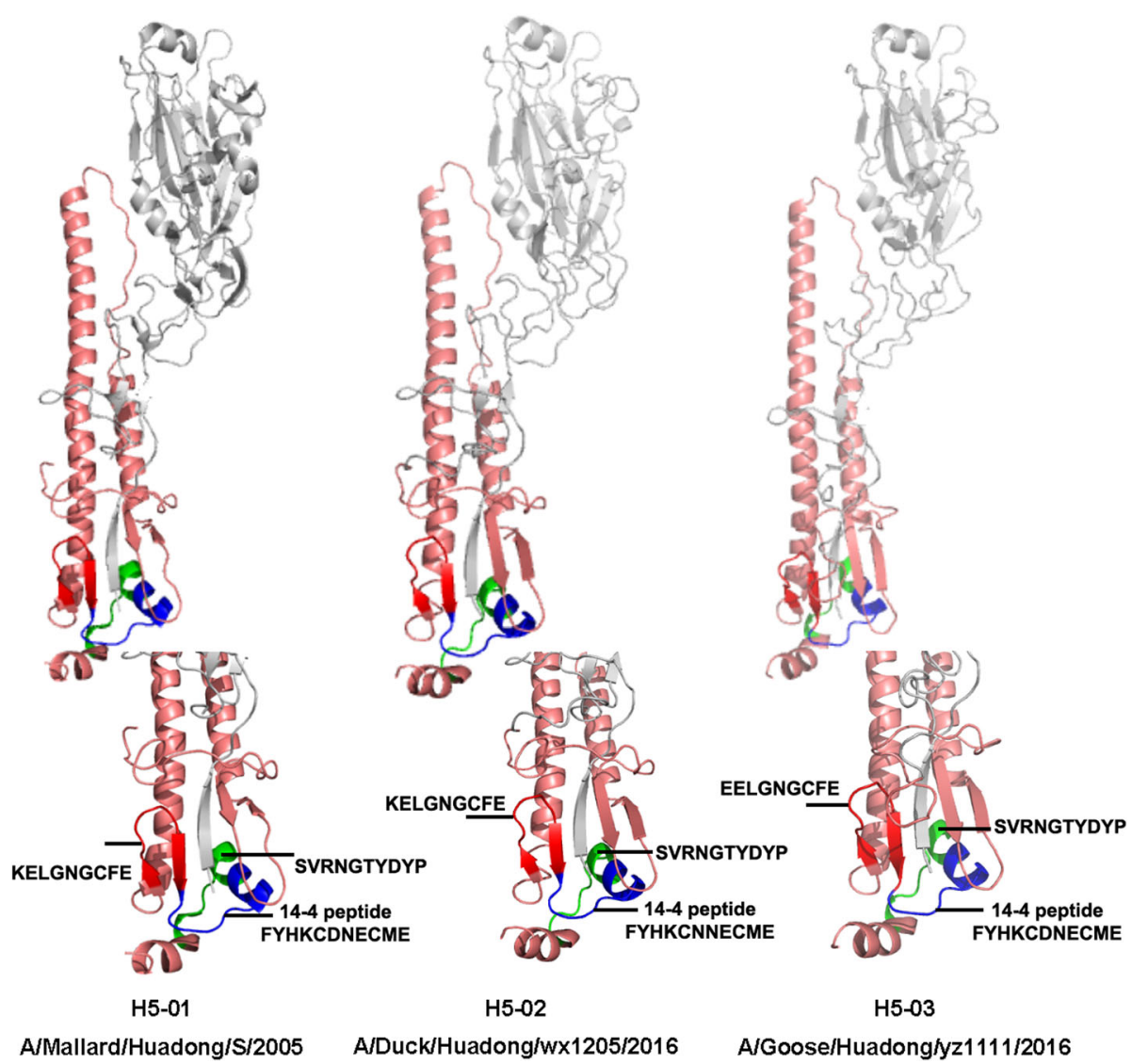

Fig. $8 \mathrm{HA}$ 3D structures of H5-01, H5-02 and H5-03. According to PDB ID 4JUK, 6NTF, and 6PCX, the HA structures of H5-01 (A/Mallard/ Huadong/S/2005), H5-02 (A/Duck/Huadong/wx1205/2016), and H5-03 (A/Goose/Huadong/yz1111/2016) were simulated through SWISS-MODEL system and analyzed by PyMOL system

Table 4 Background information of 13 influenza A viruses (IAVs) and their immunized antisera

\begin{tabular}{lll}
\hline Virus & Subtype & $\begin{array}{l}\text { HI titer of antisera } \\
\text { (nlog } \mathbf{2} \pm \text { SD) }\end{array}$ \\
\hline A/Duck/Eastern China/103/2003 & H1N1 & $7.5 \pm 0.7$ \\
A/Duck/Eastern China/852/2003 & H3N2 & $7.3 \pm 0.5$ \\
A/Duck/Eastern China/160/2002 & H4N6 & $6.5 \pm 1.1$ \\
A/Mallard/Huadong/S/2005 & H5N1 & $8.2 \pm 0.2$ \\
A/Duck/Huadong/wx1205/2016 & H5N1 & $8.0 \pm 0.0$ \\
A/Goose/Huadong/yz1111/2016 & H5N6 & $8.0 \pm 0.4$ \\
A/Duck/Eastern China/58/2003 & H6N2 & $7.3 \pm 0.5$ \\
A/Chicken/Jiangsu/W1-8/15 & H7N9 & $7.7 \pm 1.2$ \\
A/Chicken/Huadong/JD/17 & H7N9 & $8.3 \pm 0.6$ \\
A/Duck/Eastern China/01/2005 & H8N4 & $8.0 \pm 0.4$ \\
A/Chicken/Shanghai/F/98 & H9N2 & $9.0 \pm 0.4$ \\
A/Chicken/Taixing/10/2010 & H9N2 & $9.2 \pm 0.2$ \\
A/Chicken/Huadong/RD5/2013 & H10N9 & $7.5 \pm 0.7$ \\
\hline
\end{tabular}

secondary antibody (Goat Anti-Chicken $\operatorname{IgY}(\mathrm{H}+\mathrm{L})$ HRP, Abcam, USA, diluted 1:5000 with TBST). Meanwhile, protein bands of $\beta$-actin were incubated successively with the primary antibody (Anti- $\beta$-actin monoclonal antibody, Sigma Company, USA) and secondary antibody (HRP labelled anti-mouse IgG goat polyclonal antibody, Abcam, USA). Protein bands were developed using a chemiluminescence imaging analysis system (Tanon 5200, Tanon Biotech, China).

\section{Bioinformatics analysis}

HA gene sequences of IAVs available from the GISA ID (https://platform.gisaid.org/epi3/frontend) and GenBank influenza database (https://www.ncbi.nlm. nih.gov/genomes/FLU/Database/nph-select. cgi\#mainform) were aligned by MEGA 7.0 and then analyzed by WebLogo3 (http://weblogo.threeplusone. $\mathrm{com} /$ ). HA molecule was analyzed by using Protein Data Bank (PDB), SWISS-MODEL system and the PyMOL System (https://pymol.org/2/). Taking PDB 
Table 5 Amino acid sequence of synthesized peptides

\begin{tabular}{|c|c|}
\hline Peptide name & Amino acid \\
\hline $1 s t$ & GLFGAIAGFIEGGWQGMVDG \\
\hline 2nd & EGGWQGMVDGWYGYHHSNEQ \\
\hline $3 r d$ & WYGYHHSNEQGSGYAADKES \\
\hline 4 th & GSGYAADKESTQKAIDGVTN \\
\hline 5 th & TQKAIDGVTNKVNSIIDKMN \\
\hline 6th & KVNSIIDKMNTQFEAVGREF \\
\hline 7th & TQFEAVGREFNNLERRIENL \\
\hline 8th & NNLERRIENLNKKMEDGFLD \\
\hline 9th & NKKMEDGFLDWWTYNAELLV \\
\hline 10th & WWTYNAELLVLMENERTLDF \\
\hline 12th & HDSNVKNLYDKVRLQLRDNA \\
\hline 13th & KVRLQLRDNAKELGNGCFEF \\
\hline 14th & KELGNGCFEFYHKCDNECME \\
\hline 15 th & YHKCDNECMESVRNGTYDYP \\
\hline 16th & SVRNGTYDYPQYSEEARLKR \\
\hline 17th & QYSEEARLKREEISGVKLES \\
\hline 18th & EEISGVKLESIGTYQILSIY \\
\hline 19th & IGTYQILSIYSTVASSLALA \\
\hline $\mathrm{H} 7-14$ & EEDGTGCFEIFHKCDDDCMA \\
\hline $14-1$ & KELGNGCFEFY \\
\hline $14-2$ & GNGCFEFYHKC \\
\hline $14-3$ & CFEFYHKCDNE \\
\hline $14-4$ & FYHKCDNECME \\
\hline
\end{tabular}

file (PDB ID 4JUK, 6NTF, 6PCX) as a template, the amino acid sequence of target virus was modeled by Alignment Mode on SWISS-MODEL. The PDB file of HA protein of target virus was further modified with PyMOL. The epitope was also analyzed via the Immune Epitope Database (IEDB).

\section{Supplementary Information}

The online version contains supplementary material available at https://doi. org/10.1186/s12917-020-02725-5.

Additional file 1: Figure S1-S4. The signal-to-noise ratios (SNRs) of binding activity between sera from different subtype influenza $A$ viruses (IAVs) and the other H5 16 peptides (including 1th (A), 2th (B), 3th (C), 4th $(D)$, 5th $(E)$, 6th $(F)$, 7th $(G)$, 8th $(H)$, 9th $(I)$, 10th $(J)$, 12th $(K)$, 13th $(L)$, 16th $(M)$, 17th $(N)$, 18th $(O)$, or 19th (P) peptide). Synthetic peptides were sampled onto iPDMS (modified silica gel film) to form the chip. For the binding activity assay, sera were diluted 1:50 (v/v) with serum dilution buffer. Signal-to-noise ratio (SNR, SNR = signal strength-background intensity)/background intensity) was determined by GenePix Pro 6.0 software. The dotted line represents the $\mathrm{SNR}=2$. $\mathrm{H} 5-01$ : serum against $\mathrm{A} /$ Mallard/Huadong/S/2005; H5-02: serum against A/Duck/Huadong/ wx1205/2016; H5-03: serum against A/Chicken/Huadong/yz1111/2016; H5-04: serum against 2.3.4.4d vaccine strain; $H 5-05$ : serum against 2.3.2.1d vaccine strain; $H 7-01$ : serum against $A / C h i c k e n / J i a n g s u / W 1-8 / 15$; H7-02: serum against A/Chicken/Huadong/JD/17; H9-01: serum against A/Chicken/Shanghai/F/98; H9-02: serum against A/Chicken/Taixing/10/ 2010. Each reaction was repeated for 3 times, SNR values were expressed as means \pm standard deviation. $X$ axis, sera against different subtypes of IAVs; Y axis, SNR values.

Additional file 2:. Microarray data. Synthetic peptides were sampled onto iPDMS (modified silica gel film) to form the chip. For the binding activity assay, sera were diluted 1:50 ( $/ \mathrm{v}$ ) with serum dilution buffer. Signal-to-noise ratio (SNR, SNR = signal strength-background intensity)/ background intensity) was determined by GenePix Pro 6.0 software. H501: serum against A/Mallard/Huadong/S/2005; H5-02: serum against A/ Duck/Huadong/wx1205/2016; H5-03: serum against A/Chicken/Huadong/ yz1111/2016; H5-04: serum against 2.3.4.4d vaccine strain; H5-05: serum against 2.3.2.1d vaccine strain; H7-01: serum against A/Chicken/Jiangsu/ W1-8/15; H7-02: serum against A/Chicken/Huadong/JD/17; H9-01: serum against A/Chicken/Shanghai/F/98; H9-02: serum against A/Chicken/Taixing/10/2010. Each reaction was repeated for 3 times, and SNRs were expressed as means \pm standard deviation.

Additional file 3:. Original images for Western-blotting analysis. Western-blotting analysis of HA2 protein from different subtypes of influenza A viruses (Fig. 4) and mutant viruses (Fig. 7).

\section{Abbreviations}

IAV: Influenza a virus; HA: Hemagglutinin; CTL: Cytotoxic t lymphocyte; ELISA: Enzyme linked immunosorbent assay; SPF: Specific pathogen free; CEF: Chicken embryo fibroblasts; FBS: Fetal bovine serum; BSA: Bovine serum albumin; iPDMS: Modified silica gel film; TBST: Tris-buffered saline tween-20; CCD: Charge coupled device; SNR: Signal-to-noise ratio; DMEM: Dulbecco's modified eagle medium; TCID 5 : Median tissue culture infectious dose; PBS: Phosphate buffered saline; PVDF: Polyvinylidene fluoride; HRP: Horseradish peroxidase

\section{Acknowledgements}

Thanks all the teachers and students from the research group of Prof. Daxin Peng for their help.

\section{Authors' contributions}

DP, QW and ZS conceived and designed the experiments; QW, ZS and JL performed the experiments; QW wrote the paper; DP, QW and ZS analyzed the data; XL, DP, SC, HM, ZS, QW, QT and JL offered suggestions and performed some of the experiments; DP, SC and QT revised the manuscript and coordinated the research. All authors have read and approved the final manuscript.

\section{Funding}

This work was supported by the National Key R\&D Project (2017YFD0500701), the Jiangsu Agricultural Science and Technology Innovation Fund [CX (18)3018], the National Natural Science Foundation of China $(31872473,31872477,31602057)$, the Jiangsu Provincial Natural Science Foundation of China (BK20160456), the Key R\&D Project of Jiangsu Province (BE2018358), and a project funded by the Priority Academic Program Development of Jiangsu Higher Education (PAPD).

\section{Availability of data and materials}

All data generated or analyzed during this study are included in this published article and its supplementary information files.

\section{Ethics approval and consent to participate}

All animal studies were approved by the Jiangsu Administrative Committee for Laboratory Animals (Permission number: SYXKSU-2007-0005) and complied with the Guidelines of Laboratory Animal Welfare and Ethics of Jiangsu Administrative Committee for Laboratory Animals. SPF chicken were housed in cages under biosafety conditions with ad libitum access to food and water.

\section{Consent for publication}

Not applicable.

\section{Competing interests}

The authors declare that they have no competing interests. 


\section{Author details}

${ }^{1}$ College of Veterinary Medicine, Yangzhou University, 48 East Wenhui Road, Yangzhou, Jiangsu 225009, People's Republic of China. ${ }^{2}$ Jiangsu Co-Innovation Center for the Prevention and Control of Important Animal Infectious Disease and Zoonoses, Yangzhou 225009, Jiangsu, People's Republic of China. ${ }^{3}$ Jiangsu Research Centre of Engineering and Technology for Prevention and Control of Poultry Disease, Yangzhou 225009, Jiangsu, People's Republic of China. ${ }^{4}$ Division of Nanobiomedicine, Suzhou Institute of Nano-Tech and Nano-Bionics, Chinese Academy of Sciences, Suzhou 215000, People's Republic of China. ${ }^{5}$ Joint Laboratory Safety of International Cooperation of Agriculture \& Agricultural-Products, Yangzhou, Jiangsu 225009, People's Republic of China.

Received: 8 August 2020 Accepted: 15 December 2020

Published online: 07 January 2021

\section{References}

1. Graaf MD, Fouchier RAM. Role of receptor binding specificity in influenza a virus transmission and pathogenesis. EMBO J. 2014;33(8):823-41.

2. Ma MJ, Wang GL, Anderson BD, Bi ZQ, Lu B, Wang XJ, Wang CX, Chen SH, Qian YH, Song SX, Li M. Evidence for cross-species influenza a virus transmission within swine farms, China: a one health, prospective cohort study. Clin Infect Dis. 2018;66(4):533-40.

3. Biggerstaff M, Cauchemez S, Reed C, Gambhir M, Finelli L. Estimates of the reproduction number for seasonal, pandemic, and zoonotic influenza: a systematic review of the literature. BMC Infect Dis. 2014;14:480.

4. Peng Y, Li X, Zhou H, Wu A, Dong L, Zhang Y, Gao R, Bo H, Yang L, Wang $D$, Lin $X$, Jin $M$, Shu $Y$, Jiang T. Continual antigenic diversification in China leads to global antigenic complexity of avian influenza H5N1 viruses. Sci Rep. 2017;7:43566.

5. Vasin AV, Temkina OA, Egorov W, Klotchenko SA, Plotnikova MA, Kiselev Ol. Molecular mechanisms enhancing the proteome of influenza a viruses: an overview of recently discovered proteins. Virus Res. 2014;185:53-63.

6. Kumar A, Vn MA, Raut AA, Sood R, Mishra A. Identification of chicken pulmonary miRNAs targeting PB1, PB1-F2, and N40 genes of highly pathogenic avian influenza virus H5N1 in silico. Bioinform Biol Insights. 2014:8:135-45.

7. Kamal RP, Alymova IV, York IA. Evolution and virulence of influenza A virus protein PB1-F2. Int J Mol Sci. 2017;19(1):96.

8. Nachbagauer R, Wohlbold TJ, Hirsh A, Hai R, Sjursen H, Palese P, Cox RJ, Krammer $F$. Induction of broadly reactive anti-hemagglutinin stalk antibodies by an H5N1 vaccine in humans. J Virol. 2014;88(22):13260-8.

9. Tong S, Zhu X, Li Y, Shi M, Zhang J, Bourgeois M, Yang H, Chen X, Recuenco S, Gomez J, Chen LM, Johnson A, Tao Y, Dreyfus C, Yu W, McBride R, Carney PJ, Gilbert AT, Chang J, Guo Z, Davis CT, Paulson JC, Stevens J, Rupprecht CE, Holmes EC, Wilson IA, Donis RO. New world bats harbor diverse influenza a viruses. PLoS Pathog. 2013;9(10):e1003657.

10. Yoo SJ, Kwon T, Lyoo YS. Challenges of influenza a viruses in humans and animals and current animal vaccines as an effective control measure. Clin Exp Vaccine Res. 2018;7(1):1-15

11. Fan X, Hashem AM, Chen Z, Li C, Doyle T, Zhang Y, Yi Y, Farnsworth A, Xu K, Li Z, He R, Li X, Wang J. Targeting the HA2 subunit of influenza a virus hemagglutinin via CD40L provides universal protection against diverse subtypes [J]. Mucosal Immunol. 2014;8(1):211.

12. Lohia N, Baranwal M. Identification of conserved peptides comprising multiple T cell epitopes of matrix 1 protein in H1N1 influenza virus. Viral Immunol. 2015;28(10):570-9.

13. Ichihashi T, Yoshida R, Sugimoto C, Takada A, Kajino K. Cross-protective peptide vaccine against influenza a viruses developed in HLA-A*2402 human immunity model. PLoS One. 2011;6(9):e24626.

14. Gangwar RS, Shil P, Cherian SS, Gore MM. Delineation of an epitope on domain I of Japanese encephalitis virus envelope glycoprotein using monoclonal antibodies. Virus Res. 2011;158(1-2):179-87.

15. He JL, Hsieh MS, Juang RH, Wang CH. A monoclonal antibody recognizes a highly conserved neutralizing epitope on hemagglutinin of $\mathrm{H} 6 \mathrm{~N} 1$ avian influenza virus. Vet Microbiol. 2014;174(3-4):333-41.

16. Ekiert DC, Bhabha G, Elsliger MA, Friesen RHE, Jongeneelen M, Throsby M, Goudsmit J, Wilson IA. Antibody recognition of a highly conserved influenza virus epitope. Science. 2009;324(5924):246-51.

17. Li Z, Wan Z, Li T, Xie Q, Sun H, Chen H, Liang G, Shao H, Qin A, Ye J. A novel linear epitope crossing group 1 and group 2 influenza a viruses located in the helix a of HA2 derived from H7N9. Vet Microbiol. 2019;228: 39-44.

18. Zhu Y, Yang D, Ren Q, Yang Y, Liu X, Xu X, Liu W, Chen S, Peng D, Liu X. Identification and characterization of a novel antigenic epitope in the hemagglutinin of the escape mutants of H9N2 avian influenza viruses. Vet Microbiol. 2015;178(1-2):144-9.

19. Khurana S, Sasono P, Fox A, Nguyen VK, Golding H. H5N1-serodetect ElA and rapid test: a novel differential diagnostic assay for serodiagnosis of H5N1 infections and surveillance. J Virol. 2011;85(23):12455-63.

20. Neuvirth H, Raz R, Schreiber G. ProMate: a structure based prediction program to identify the location of protein-protein binding sites. J Mol Biol. 2004;338(1):181-99.

21. Babon JAB, Cruz J, Orphin L, Pazoles P, Co MDT, Ennis FA, Terajima M. Genome-wide screening of human T-cell epitopes in influenza a virus reveals a broad spectrum of CD4+ T-cell responses to internal proteins, hemagglutinins, and neuraminidases. Hum Immunol. 2009;70(9):711-21.

22. Richards KA, Chaves FA, Sant AJ. The memory phase of the CD4 T-cell response to influenza virus infection maintains its diverse antigen specificity. Immunology. 2011;133(2):246-56.

23. Richards KA, Chaves FA, Krafcik FR, Topham DJ, Lazarski CA, Sant AJ. Direct ex vivo analyses of HLA-DR1 transgenic mice reveal an exceptionally broad pattern of immunodominance in the primary HLA-DR1-restricted CD4 T-cell response to influenza virus hemagglutinin. J Virol. 2007;81(14):7608-19.

24. Zhao RM, Cui SJ, Guo L, Wu C, Gonzalez R, Paranhos-Baccala G, Vernet G, Wang JW, Hung T. Identification of a highly conserved H1 subtype-specific epitope with diagnostic potential in the hemagglutinin protein of influenza a virus. PLoS One. 2011;6(8):e23374.

25. Butler $D$. The ghost of influenza past and the hunt for a universal vaccine. Nature. 2018:560(7717):158-60.

26. Coughlan L, Palese P. Overcoming barriers in the path to a universal influenza virus vaccine. Cell Host Microbe. 2018;24(1):18-24.

27. Krammer F, García-Sastre A, Palese P. Is it possible to develop a "universal" influenza virus vaccine? Toward a universal influenza virus vaccine: potential target antigens and critical aspects for vaccine development. Cold Spring Harb Perspect Biol. 2017;10(7):a028845.

28. Paules Cl, Fauci AS. A universal flu vaccine is vital. Sci Am. 2018;318(2):8-8.

29. Rajão DS, Pérez DR. Universal vaccines and vaccine platforms to protect against influenza viruses in humans and agriculture. Front Microbiol. 2018;9: 123.

30. Ekiert DC, Friesen RHE, Bhabha G, Kwaks T, Jongeneelen M, Yu W, Ophorst C, Cox F, Korse HJWM, Brandenburg B, Vogels R, Brakenhoff JPJ, Kompier R, Koldijk MH, Cornelissen LAHM, Poon LLM, Peiris M, Koudstaal W, Wilson IA, Goudsmit J. A highly conserved neutralizing epitope on group 2 influenza a viruses. Science. 2011;333(6044):843-50.

31. Margine I, Krammer F, Hai R, Heaton NS, Tan GS, Andrews SA, Runstadler JA, Wilson PC, Albrecht RA, García-Sastre A, Palese P. Hemagglutinin stalk-based universal vaccine constructs protect against group 2 influenza a viruses. J Virol. 2013;87(19):10435-46.

32. Krammer F, Palese $P$, Steel J. Advances in universal influenza virus vaccine design and antibody mediated therapies based on conserved regions of the hemagglutinin. Curr Top Microbiol Immunol. 2015;386:301-21.

33. Corti D, Voss J, Gamblin SJ, Codoni G, Macagno A, Jarrossay D, Vachieri SG, Pinna D, Minola A, Vanzetta F, Silacci C, Fernandez-Rodriguez BM, Agatic G, Bianchi S, Giacchetto-Sasselli I, Calder L, Sallusto F, Collins P, Haire LF, Temperton N, Langedijk JPM, Skehel JJ, Lanzavecchia A. A neutralizing antibody selected from plasma cells that binds to group 1 and group 2 influenza a hemagglutinins. Science. 2011;333(6044):850-6.

34. Su M, Li T, Liu DJ, Wang ZX. A peptide microarray-based fluorescent and resonance light scattering assay for screening thrombin inhibitor. Chin J Anal Chem. 2015;43(2):199-205.

35. Chen JX, Chen MX, Ai L, Chen JH, Chen SH, Zhang YN, Cai YC, Zhu XQ, Zhou XN. A protein microarray for the rapid screening of patients suspected of infection with various food-borne helminthiases. PLoS Negl Trop Dis. 2012;6(11):e1899.

36. Lu YD, Li Z, Teng H, Xu HK, Qi SN, He JA, Gu DY, Chen QJ, Ma HW. Chimeric peptide constructs comprising linear B-cell epitopes: application to the serodiagnosis of infectious diseases. Sci Rep. 2015;5:13364.

37. Sachse K, Rahman KS, Schnee C, Muller E, Peisker M, Schumacher T, Schubert E, Ruettger A, Kaltenboeck B, Ehricht R. A novel synthetic peptide microarray assay detects chlamydia species-specific antibodies in animal and human sera. Sci Rep. 2018;8:4701. 
38. Braakman I, Helenius J, Helenius A. Manipulating disulfide bond formation and protein folding in the endoplasmic reticulum. EMBO J. 1992;11(5):1717-22.

39. Xu S, Zhou J, Liu K, Liu Q, Xue C, Li X. Mutations of two transmembrane cysteines of hemagglutinin (HA) from influenza a $\mathrm{H} 3 \mathrm{~N} 2$ virus affect $\mathrm{HA}$ thermal stability and fusion activity. Virus Genes. 2013;47(1):20-6.

40. Holtz KM, Robinson PS, Matthews EE, Hashimoto Y, McPherson CE, Khramtsov N, Reifler MJ, Meghrous J, Rhodes DG, Cox MM. Modifications of cysteine residues in the transmembrane and cytoplasmic domains of a recombinant hemagglutinin protein prevent cross-linked multimer formation and potency loss. BMC Biotechnol. 2014;14(1):111.

41. Guo C, Zhang H, Xie X, Liu Y, Sun L, Li H, Yu P, Hu H, Sun J, Li Y, Feng Q Zhao X, Liang D, Wang Z, Hu J. H1N1 influenza virus epitopes classified by monoclonal antibodies. Exp Ther Med. 2018;16(3):2001-7.

42. Wang Z, Huang B, Thomas M, Sreenivasan CC, Sheng Z, Yu J, Hause BM, Wang D, Francis DH, Kaushik RS, Li F. Detailed mapping of the linear B cell epitopes of the hemagglutinin (HA) protein of swine influenza virus. Virology. 2018;522:131-7.

43. Shi S, Chen S, Han W, Wu B, Zhang X, Tang Y, Wang X, Zhu Y, Peng D, Liu $X$. Cross-clade protective immune responses of NS1-truncated live attenuated H5N1 avian influenza vaccines. Vaccine. 2016;34(3):350-7.

44. Zhao X, Zhou Z, Chen Y, Chen W, Ma H, Pu J. Role of antibodies to human papillomavirus 16 in prostate cancer: a seroscreening by peptide microarray. Tumour Biol. 2017;39(6):1010428317698371.

45. Hoffmann E, Stech J, Guan Y, Webster RG, Perez DR. Universal primer set for the full-length amplification of all influenza a viruses. Arch Virol. 2001; 146(12):2275-89.

46. Hoffmann E, Neumann G, Kawaoka Y, Hobom G, Webster RG. A DNA transfection system for generation of influenza a virus from eight plasmids. Proc Natl Acad Sci U S A. 2000;97(11):6108-13.

47. Wagner R, Wolff T, Herwig A, Pleschka S, Klenk HD. Interdependence of hemagglutinin glycosylation and neuraminidase as regulators of influenza virus growth: a study by reverse genetics. J Virol. 2000;74(14):6316-23.

\section{Publisher's Note}

Springer Nature remains neutral with regard to jurisdictional claims in published maps and institutional affiliations.

Ready to submit your research? Choose BMC and benefit from:

- fast, convenient online submission

- thorough peer review by experienced researchers in your field

- rapid publication on acceptance

- support for research data, including large and complex data types

- gold Open Access which fosters wider collaboration and increased citations

- maximum visibility for your research: over $100 \mathrm{M}$ website views per year

At $\mathrm{BMC}$, research is always in progress.

Learn more biomedcentral.com/submissions 